\title{
Utilization of the post-filtration lye from the SCS method of soda production
}

\author{
Mieczysław Trypuć, Sebastian Drużyński, Urszula Kiełkowska, Krzysztof Mazurek \\ N. Copernicus University, Faculty of Chemistry, Department of Chemical Technology, ul. Gagarina 7, 87-100 Toruń, \\ ${ }^{1}$ Corresponding author: e-mail: sebdru@uni.torun.pl
}

\begin{abstract}
The mutual solubility of salts in the $\mathrm{NaVO}_{3}-\mathrm{NaNO}_{3}-\mathrm{H}_{2} \mathrm{O}$ system was investigated at $293-323 \mathrm{~K}$ temperature range by the method of isothermal saturation of solutions. A fragment of the solubility polytherm for that system was plotted, based on the obtained data. The investigated system is a part of the quaternary $\mathrm{NH}_{4} \mathrm{NO}_{3}-$ $\mathrm{NaVO}_{3}-\mathrm{NH}_{4} \mathrm{VO}_{3}-\mathrm{NaNO}_{3}$ system, and it is necessary for plotting the solubility isotherm as a planar projection according to Janecke, since it defines one edge of its square. Knowledge of the isotherm for that quaternary system is necessary to determine the optimal utilization conditions for the post-filtration lye, formed during the soda production from $\mathrm{NaNO}_{3}$ by the Solvay method, using $\mathrm{NaVO}_{3}$.
\end{abstract}

Keywords: mutual solubility, sodium metavanadate, sodium nitrate, ternary system.

Presented at VII Conference Wasteless Technologies and Waste Management in Chemical Industry and Agriculture, Międzyzdroje, 12 - 15 June, 2007.

\section{INTRODUCTION}

The SCS method (Soda-Chlorine-Saltpetre) is a modification of the classic Solvay method of soda production ${ }^{1,2}$. Generally, it is based on the carbonization of the ammoniated $\mathrm{NaNO}_{3}$ brine. Sodium bicarbonate obtained in that process is subjected to calcination ${ }^{1-3}$ (equations 1 and 2). $\mathrm{NaNO}_{3}+\mathrm{NH}_{3}+\mathrm{CO}_{2}+\mathrm{H}_{2} \mathrm{O} \rightarrow \mathrm{NaHCO}_{3}+\mathrm{NH}_{4} \mathrm{NO}_{3}$

$2 \mathrm{NaHCO}_{3} \stackrel{Q}{\longrightarrow} \mathrm{Na}_{2} \mathrm{CO}_{3}+\mathrm{CO}_{2}+\mathrm{H}_{2} \mathrm{O}$

Sodium nitrate required for that process is obtained in a reaction of the oxidation of solid sodium chloride with nitric acid according to equation 3.

$4 \mathrm{NaCl}+4 \mathrm{HNO}_{3}+\mathrm{O}_{2} \leftrightarrow 4 \mathrm{NaNO}_{3}+2 \mathrm{Cl}_{2}+2 \mathrm{H}_{2} \mathrm{O}$

After the filtration of sodium bicarbonate sediment, the lye is obtained, with the composition depending on the carbonization conditions. The major components of that lye are ammonium nitrate (ca. $80 \%$ ), unreacted sodium nitrate $18 \%$ and sodium chloride from the oxidation process $2 \%$, as recalculated to the solid mass ${ }^{\mathbf{1}, 2}$.

So far it has been suggested that the lye might be used as a raw material for the production of mixed ammoniumsodium saltpetre, which is a nitrogenous fertilizer ${ }^{1,2}$. However, concentration of that solution for crystallizing the salts is difficult due to the explosive properties of ammonium nitrate. The presence of chlorides catalyzing the uncontrolled decomposition of ammonium nitrate, ${ }^{4,}$, is especially disadvantageous.

The aim of the research is to eliminate the danger occurring during the recovery of solid ammonium-sodium nitrate by the evaporation of the post-filtration solution in the process of soda production with the SCS method, as well as to improve the material and economical efficiency of that method.

The research on partial utilization of the post-filtration lye from the classic Solvay method, indicates the possibility of the use of sodium vanadate $(\mathrm{V})$ instead of calcium hydroxide suspension ${ }^{6,7}$. That approach to the utilization of the post-filtration lye from the SCS method is based on a reaction of sodium vanadate $(\mathrm{V})$ with ammonium nitrate, present in the solution, according to equation ${ }^{4}$.

$\mathrm{NH}_{4} \mathrm{NO}_{3}+\mathrm{NaVO}_{3} \leftrightarrow \mathrm{NH}_{4} \mathrm{VO}_{3}+\mathrm{NaNO}_{3}$
After the reaction, the precipitated sparingly soluble ammonium vanadate is washed with water and subjected to calcination according to equation (5).

$2 \mathrm{NH}_{4} \mathrm{VO}_{3} \stackrel{Q}{\longrightarrow} 2 \mathrm{NH}_{3}+\mathrm{V}_{2} \mathrm{O}_{5}+\mathrm{H}_{2} \mathrm{O}$

Ammonia from reaction (5) is recycled to the step of ammonization of sodium nitrate brine, while vanadium $(\mathrm{V})$ oxide reacts with sodium chloride in the presence of oxygen $^{8}$ (equation 6) forming sodium vanadate(V), which is recycled into reaction (4).

$2 \mathrm{~V}_{2} \mathrm{O}_{5}+4 \mathrm{NaCl}+\mathrm{O}_{2} \stackrel{Q}{\longrightarrow} 4 \mathrm{NaVO}_{3}+2 \mathrm{Cl}_{2}$

The solution after the filtration of $\mathrm{NH}_{4} \mathrm{VO}_{3}$ contains the remaining sodium nitrate. That lye is concentrated, saturated with solid sodium nitrate, and then recycled into the step of ammonization of the $\mathrm{NaNO}_{3}$ brine. The previous research ${ }^{1,2}$ indicated that the small amount of sodium chloride does not have the negative effect on the production of $\mathrm{NaHCO}_{3}$.

Utilization of the post-filtration lye from the SCS method with sodium vanadate $(\mathrm{V})$ improves the material and the economic efficiency of the soda production by:

- recovery of sodium nitrate, which circulates in the closed cycle, which results in the smaller use of nitric acid required for the production of that reagent,

- limiting the chlorine production, resulting from the amount of the recycled unreacted sodium nitrate in the process of $\mathrm{NaHCO}_{3}$ production,

- practically a complete recovery of ammonia, which circulates in the closed cycle.

The economical control of the utilization of the postfiltration lye from the SCS method with the use of $\mathrm{NaVO}_{3}$ requires precise knowledge of the equilibrium plot for the

$\mathrm{NH}_{4} \mathrm{NO}_{3}-\mathrm{NaVO}_{3}-\mathrm{H}_{2} \mathrm{O}$ reciprocal salt pairs system in the planar projection according to Janecke. Such plotting of the isotherm requires a research on equilibrium in four ternary subsystems: $\mathrm{NaNO}_{3}-\mathrm{NaVO}_{3}-\mathrm{H}_{2} \mathrm{O}, \mathrm{NH}_{4} \mathrm{NO}_{3}-$ $\mathrm{NH}_{4} \mathrm{VO}_{3}-\mathrm{H}_{2} \mathrm{O}, \mathrm{NaNO}_{3}-\mathrm{NH}_{4} \mathrm{NO}_{3}-\mathrm{H}_{2} \mathrm{O}, \mathrm{NaVO}_{3}-$ $\mathrm{NH}_{4} \mathrm{VO}_{3}-\mathrm{H}_{2} \mathrm{O}$, which are positioned on the respective edges and inside the square equilibrium plot, to determine the border lines limiting the areas of co-crystallization of specific salts and the triple points.

The literature data on the ternary systems mentioned above are incomplete, and there are no reports on the 
quaternary system. The complete data have been found only for the

$\mathrm{NaVO}_{3}-\mathrm{NH}_{4} \mathrm{VO}_{3}-\mathrm{H}_{2} \mathrm{O}$ system at $293-323 \mathrm{~K}^{9}$, while partial data are available for the $\mathrm{NaNO}_{3}-\mathrm{NH}_{4} \mathrm{NO}_{3}-\mathrm{H}_{2} \mathrm{O}$ system $^{2}$. Therefore, we decided to investigate the mutual solubility of $\mathrm{NaVO}_{3}$ and $\mathrm{NaNO}_{3}$ in water at $293-323 \mathrm{~K}$ temperature range.

\section{EXPERIMENTAL}

\section{Reagents}

In the research, the analytical grade reagents were used, $\mathrm{NaVO}_{3}$ ( $\geq 98$ wt.\% Fluka), $\mathrm{NaNO}_{3}$ (pure for analysis POCh Gliwice).

\section{Method}

Determination of the mutual solubility in the $\mathrm{NaNO}_{3}$ $\mathrm{NaVO}_{3}-\mathrm{H}_{2} \mathrm{O}$ system was performed at 293, 303, 313 and $323 \mathrm{~K}$, with the method of the isothermal saturation of solutions. The required amounts of components, one of which was in excess relative to its solubility in water, were put into the $100 \mathrm{~cm}^{3}$ Erlenmeyer flasks with $80 \mathrm{~cm}^{3}$ of the re-distilled water. Then the flasks were put into the water thermostat and stirred with the magnetic stirrer. The required temperature was maintained with the Polystat CC1 thermostat, with a $\pm 0.02 \mathrm{~K}$ precision, controlled with the mercury thermometer with the $\pm 0.1 \mathrm{~K}$ precision. The time of equilibration between the solid and liquid phases was determined experimentally as $100 \mathrm{~h}$. After that time the stirring was stopped, and after the sedimentation for $1 \mathrm{~h}$, the samples of clean equilibrated solution were transferred into the pre-calibrated Ostwald pycnometer for the density measurements. The density was determined gravimetrically with the precision of $\pm 0.002 \mathrm{~g} \cdot \mathrm{cm}^{-3}$. The samples were collected under the pressure increased with the use of a micrometering pump, which prevented the crystallization of the solution components, especially at higher temperatures. The pycnometer contents was subsequently transferred quantitatively into a measuring flask and diluted to $500 \mathrm{~cm}^{3}$ with the re-distilled water. The composition of the obtained solutions was determined during the chemical analyses. The concentration of sodium and vanadate ions was determined.

Three independent analyses were performed for each collected sample. The precision of the analyses was estimated by the Relative Standard Deviation (RSD) error, which had not exceeded $2 \%$. The nitrate concentration was calculated based on the difference between the concentrations of sodium and vanadate ions.

\section{Analytical methods}

The concentration of sodium ions in the equilibrated solutions was determined gravimetrically with the Kolthoff and Barber method as sodium-zinc-uranyl acetate ${ }^{\mathbf{1 0}, 11}$.

Vanadium(V) was determined spectrophotometrically as a complex with the hydrogen peroxide. The analyses were performed with the double-beam UV-VIS Hitachi U-2000 spectrophotometer in the quartz cells with the 10 mm optical way. Vanadium(V) in the concentrated sulfuric acid (1:3) in a presence of $3 \mathrm{wt} . \%$ aqueous solution of $\mathrm{H}_{2} \mathrm{O}_{2}$ forms the compounds $\mathrm{V}\left(\mathrm{O}_{2}\right) \mathrm{X}_{3}$ and/or $\mathrm{V}\left(\mathrm{O}_{2}\right) \mathrm{X}_{5}^{2}$, where $\mathrm{X}$ is the monovalent anion. That reaction goes in the equimolar ratio according to equation $(7)^{11}$.

$(\mathrm{VO})_{2}\left(\mathrm{SO}_{4}\right)_{3}+2 \mathrm{H}_{2} \mathrm{O}_{2} \leftrightarrow\left[\mathrm{V}\left(\mathrm{O}_{2}\right)\right]_{2}\left(\mathrm{SO}_{4}\right)_{3}+2 \mathrm{H}_{2} \mathrm{O}$ (7)

These compounds reveal maximum absorbancy at 450 $\mathrm{nm}$, and the molar absorbancy is $300 \mathrm{dm}^{3} \cdot \mathrm{mol}^{-1} \cdot \mathrm{cm}^{-1}$. The system obeys the Beer law in a broad range of concentrations between $8 \cdot 10^{-3}$ and $2 \mathrm{~mol} \cdot \mathrm{dm}^{-311}$.

For the solutions with very low concentration, below $2 \cdot 10^{-2} \mathrm{~mol} \cdot \mathrm{dm}^{-3}$, the spectrophotometric method with 4(2-pyridylazo)resorcinol (PAR) was used. The analyses were performed with the double-beam UV-VIS Hitachi U-2000 spectrophotometer in the quartz cells with the 10 mm optical way. At $\mathrm{pH}$ 5-6 vanadium(V) compounds form complexes with PAR with the maximum absorbancy at $540 \mathrm{~nm}$. The maximum color saturation appears after $30 \mathrm{~min}$, and remains steady for 2 hours. The molar absorbancy is $3.6 \cdot 10^{4} \mathrm{dm}^{3} \cdot \mathrm{mol}^{-1} \cdot \mathrm{cm}^{-1} \mathbf{1 1}$.

For the selected experimental points, the analyses of the solid phase were performed with the X-ray powder diffractometer Philips X-Pert PRO System. To determine the solid phase composition, the diffraction data were compared to the standards included in the „Powder Diffraction File"12.

\section{RESULTS AND DISCUSSION}

The experimental data on the mutual solubility of $\mathrm{NaVO}_{3}$ and $\mathrm{NaNO}_{3}$ in the

$\mathrm{NaVO}_{3}-\mathrm{NaNO}_{3}-\mathrm{H}_{2} \mathrm{O}$ system are presented in Table 1. For four temperatures, the equilibrium concentrations of salts in $\mathrm{mol} \cdot \mathrm{dm}^{-3}$, the density of the equilibrated solutions in $\mathrm{g} \cdot \mathrm{cm}^{-3}$ and the molar ratios, without taking into account the solvent and the solid phase composition, are tabulated.

The molar ratios, without taking into account the solvent, were calculated as follows:

$X_{\mathrm{NaVO}_{3}}=\frac{\left[\mathrm{NaVO}_{3}\right]}{\left[\mathrm{NaVO}_{3}\right]+\left[\mathrm{NaNO}_{3}\right]}, X_{\mathrm{NaNO}_{3}}=\frac{\left[\mathrm{NaNO}_{3}\right]}{\left[\mathrm{NaVO}_{3}\right]+\left[\mathrm{NaNO}_{3}\right]}$

A fragment of the polytherm for the investigated system was plotted for the temperature range $293-323 \mathrm{~K}$, based on the data from Table 1, and presented in Figures 1 and 2. Figure 1 presents the branches II of the solubility isotherms, that correspond to the solutions saturated with sodium vanadate $(\mathrm{V})$. Their characteristic course indicates

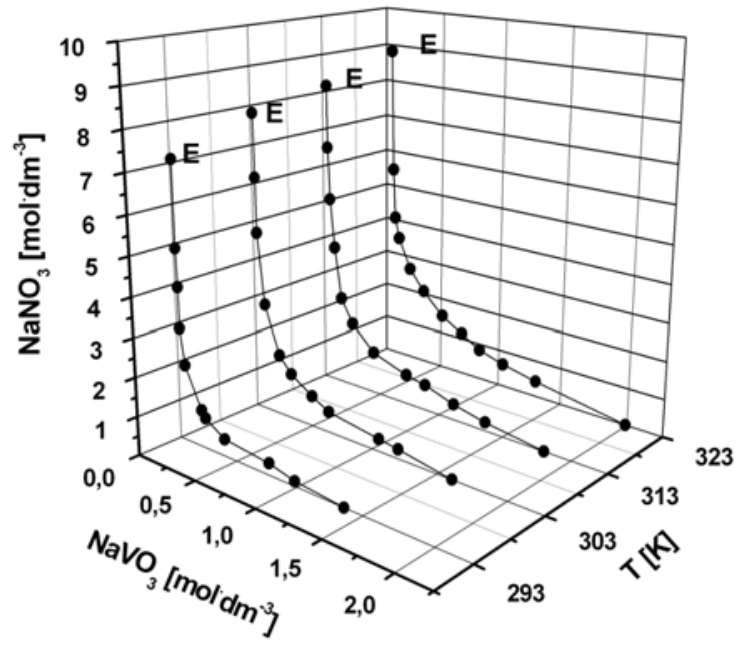

Figure 1. Branches II of the solubility isotherms for $\mathrm{NaVO}_{3}$ $\mathrm{NaNO}_{3}-\mathrm{H}_{2} \mathrm{O}$ system 
Table 1. The solubility in the $\mathrm{NaVO}_{3}-\mathrm{NaNO}_{3}-\mathrm{H}_{2} \mathrm{O}$ system

\begin{tabular}{|c|c|c|c|c|c|c|}
\hline \multirow[t]{2}{*}{ No. } & \multirow{2}{*}{$\begin{array}{c}\rho \\
\left(\mathrm{g} \cdot \mathrm{cm}^{-3}\right)\end{array}$} & \multicolumn{2}{|c|}{$\begin{array}{c}c \\
\left(\mathrm{~mol} \cdot \mathrm{dm}^{-3}\right)\end{array}$} & \multicolumn{2}{|c|}{$x$} & \multirow[t]{2}{*}{ Solid phase composition } \\
\hline & & $\mathrm{NaVO}_{3}$ & $\mathrm{NaNO}_{3}$ & $\mathrm{NaVO}_{3}$ & $\mathrm{NaNO}_{3}$ & \\
\hline \multicolumn{7}{|c|}{$\mathrm{T}=293 \mathrm{~K}$} \\
\hline 1 & 1.392 & 0 & 7.317 & 0 & 1 & $\mathrm{NaNO}_{3}$ \\
\hline 2 & 1.390 & 0.003 & 7.255 & 0.0002 & 0.9998 & $\mathrm{NaNO}_{3}$ \\
\hline 3 & 1.392 & 0.009 & 7.176 & 0.0007 & 0.9993 & $\mathrm{NaNO}_{3}$ \\
\hline $4(\mathrm{E})$ & 1.392 & 0.013 & 7.099 & 0.0010 & 0.9990 & $\mathrm{NaNO}_{3}+\mathrm{NaVO}_{3}$ \\
\hline 5 & 1.254 & 0.016 & 4.910 & 0.0021 & 0.9979 & $\mathrm{NaVO}_{3}$ \\
\hline 6 & 1.195 & 0.027 & 3.934 & 0.0049 & 0.9951 & $\mathrm{NaVO}_{3}$ \\
\hline 7 & 1.154 & 0.028 & 2.883 & 0.0075 & 0.9925 & $\mathrm{NaVO}_{3}$ \\
\hline 8 & 1.112 & 0.066 & 1.976 & 0.0277 & 0.9723 & $\mathrm{NaVO}_{3}$ \\
\hline 9 & 1.069 & 0.203 & 0.958 & 0.1668 & 0.8332 & $\mathrm{NaVO}_{3}$ \\
\hline 10 & 1.063 & 0.236 & 0.780 & 0.2254 & 0.7746 & $\mathrm{NaVO}_{3}$ \\
\hline 11 & 1.060 & 0.398 & 0.436 & 0.4797 & 0.5203 & $\mathrm{NaVO}_{3}$ \\
\hline 12 & 1.088 & 0.775 & 0.303 & 0.7325 & 0.2675 & $\mathrm{NaVO}_{3}$ \\
\hline 13 & 1.108 & 0.982 & 0.130 & 0.8937 & 0.1063 & $\mathrm{NaVO}_{3}$ \\
\hline 14 & 1.118 & 1.360 & 0 & 1 & 0 & $\mathrm{NaVO}_{3}$ \\
\hline \multicolumn{7}{|c|}{$\mathrm{T}=303 \mathrm{~K}$} \\
\hline 1 & 1.412 & 0 & 7.890 & 0 & 1 & $\mathrm{NaNO}_{3}$ \\
\hline 2 & 1.412 & 0.003 & 7.877 & 0.0002 & 0.9998 & $\mathrm{NaNO}_{3}$ \\
\hline 3 & 1.412 & 0.008 & 7.862 & 0.0005 & 0.9995 & $\mathrm{NaNO}_{3}$ \\
\hline $4(E)$ & 1.417 & 0.019 & 7.824 & 0.0013 & 0.9987 & $\mathrm{NaNO}_{3}+\mathrm{NaVO}_{3}$ \\
\hline 5 & 1.307 & 0.027 & 6.165 & 0.0026 & 0.9974 & $\mathrm{NaVO}_{3}$ \\
\hline 6 & 1.253 & 0.033 & 4.731 & 0.0048 & 0.9952 & $\mathrm{NaVO}_{3}$ \\
\hline 7 & 1.155 & 0.092 & 2.850 & 0.0251 & 0.9749 & $\mathrm{NaVO}_{3}$ \\
\hline 8 & 1.108 & 0.216 & 1.601 & 0.1080 & 0.8920 & $\mathrm{NaVO}_{3}$ \\
\hline 9 & 1.092 & 0.318 & 1.193 & 0.2003 & 0.7997 & $\mathrm{NaVO}_{3}$ \\
\hline 10 & 1.084 & 0.496 & 0.800 & 0.3807 & 0.6193 & $\mathrm{NaVO}_{3}$ \\
\hline 11 & 1.090 & 0.640 & 0.541 & 0.5499 & 0.4501 & $\mathrm{NaVO}_{3}$ \\
\hline 12 & 1.110 & 1.049 & 0.321 & 0.7825 & 0.2175 & $\mathrm{NaVO}_{3}$ \\
\hline 13 & 1.114 & 1.201 & 0.246 & 0.8462 & 0.1538 & $\mathrm{NaVO}_{3}$ \\
\hline 14 & 1.135 & 1.609 & 0 & 1 & 0 & $\mathrm{NaVO}_{3}$ \\
\hline \multicolumn{7}{|c|}{$\mathrm{T}=313 \mathrm{~K}$} \\
\hline 1 & 1.418 & 0 & 8.298 & 0 & 1 & $\mathrm{NaNO}_{3}$ \\
\hline 2 & 1.418 & 0.014 & 8.268 & 0.0009 & 0.9991 & $\mathrm{NaNO}_{3}$ \\
\hline 3 & 1.418 & 0.024 & 8.200 & 0.0015 & 0.9985 & $\mathrm{NaNO}_{3}$ \\
\hline $4(E)$ & 1.419 & 0.037 & 8.178 & 0.0023 & 0.9977 & $\mathrm{NaNO}_{3}+\mathrm{NaVO}_{3}$ \\
\hline 5 & 1.270 & 0.040 & 6.523 & 0.0035 & 0.9965 & $\mathrm{NaVO}_{3}$ \\
\hline 6 & 1.220 & 0.059 & 5.108 & 0.0074 & 0.9926 & $\mathrm{NaVO}_{3}$ \\
\hline 7 & 1.204 & 0.097 & 3.783 & 0.0186 & 0.9814 & $\mathrm{NaVO}_{3}$ \\
\hline 8 & 1.141 & 0.156 & 2.386 & 0.0517 & 0.9483 & $\mathrm{NaVO}_{3}$ \\
\hline 9 & 1.114 & 0.256 & 1.754 & 0.1152 & 0.8848 & $\mathrm{NaVO}_{3}$ \\
\hline 10 & 1.098 & 0.442 & 1.124 & 0.2739 & 0.7261 & $\mathrm{NaVO}_{3}$ \\
\hline 11 & 1.107 & 0.728 & 0.803 & 0.4808 & 0.5192 & $\mathrm{NaVO}_{3}$ \\
\hline 12 & 1.107 & 0.885 & 0.699 & 0.5704 & 0.4296 & $\mathrm{NaVO}_{3}$ \\
\hline 13 & 1.121 & 1.118 & 0.423 & 0.7442 & 0.2558 & $\mathrm{NaVO}_{3}$ \\
\hline 14 & 1.130 & 1.366 & 0.229 & 0.8729 & 0.1271 & $\mathrm{NaVO}_{3}$ \\
\hline 15 & 1.150 & 1.808 & 0 & 1 & 0 & $\mathrm{NaVO}_{3}$ \\
\hline \multicolumn{7}{|c|}{$\mathrm{T}=323 \mathrm{~K}$} \\
\hline 1 & 1.431 & 0 & 8.959 & 0 & 1 & $\mathrm{NaNO}_{3}$ \\
\hline 2 & 1.431 & 0.011 & 8.902 & 0.0006 & 0.9994 & $\mathrm{NaNO}_{3}$ \\
\hline 3 & 1.431 & 0.035 & 8.837 & 0.0019 & 0.9981 & $\mathrm{NaNO}_{3}$ \\
\hline $4(E)$ & 1.431 & 0.052 & 8.819 & 0.0028 & 0.9972 & $\mathrm{NaNO}_{3}+\mathrm{NaVO}_{3}$ \\
\hline 5 & 1.268 & 0.063 & 5.457 & 0.0073 & 0.9927 & $\mathrm{NaVO}_{3}$ \\
\hline 6 & 1.204 & 0.082 & 4.058 & 0.0143 & 0.9857 & $\mathrm{NaVO}_{3}$ \\
\hline 7 & 1.181 & 0.116 & 3.478 & 0.0248 & 0.9752 & $\mathrm{NaVO}_{3}$ \\
\hline 8 & 1.144 & 0.220 & 2.639 & 0.0643 & 0.9357 & $\mathrm{NaVO}_{3}$ \\
\hline 9 & 1.125 & 0.345 & 2.078 & 0.1268 & 0.8732 & $\mathrm{NaVO}_{3}$ \\
\hline 10 & 1.112 & 0.513 & 1.509 & 0.2418 & 0.7582 & $\mathrm{NaVO}_{3}$ \\
\hline 11 & 1.110 & 0.684 & 1.147 & 0.3701 & 0.6299 & $\mathrm{NaVO}_{3}$ \\
\hline 12 & 1.110 & 0.839 & 0.831 & 0.5100 & 0.4900 & $\mathrm{NaVO}_{3}$ \\
\hline 13 & 1.114 & 1.037 & 0.623 & 0.6415 & 0.3585 & $\mathrm{NaVO}_{3}$ \\
\hline 14 & 1.130 & 1.303 & 0.421 & 0.7772 & 0.2228 & $\mathrm{NaVO}_{3}$ \\
\hline 15 & 1.164 & 1.987 & 0 & 1 & 0 & $\mathrm{NaVO}_{3}$ \\
\hline
\end{tabular}

the salting-out effect of sodium nitrate on sodium vanadate $(\mathrm{V})$. The data in Table 1 reveals only the small solubility of $\mathrm{NaVO}_{3}$ in the saturated $\mathrm{NaNO}_{3}$ solutions, which is shown in Fig. 2 for better clarity. The course of branches I of isotherms in Fig. 2 are linear with the negative slope, which indicates the small salting-out effect of sodium vanadate $(\mathrm{V})$ on sodium nitrate.

Strong salting-out effect of sodium nitrate on sodium vanadate $(V)$ is advantageous for the reaction (4) equilib- rium. However, kinetically that effect is undesired. The kinetics of reaction (4) depends on the rate of sodium vanadate $(\mathrm{V})$ solubilization. Due to the reaction progress, the increasing concentration of sodium nitrate results in the decreased rate of sodium vanadate $(\mathrm{V})$ solubilization and slowing down the reaction.

The course of the isotherms in Figures 1 and 2 leads to the preliminary conclusion that no new solid phase is formed in the investigated system. That conclusion might 


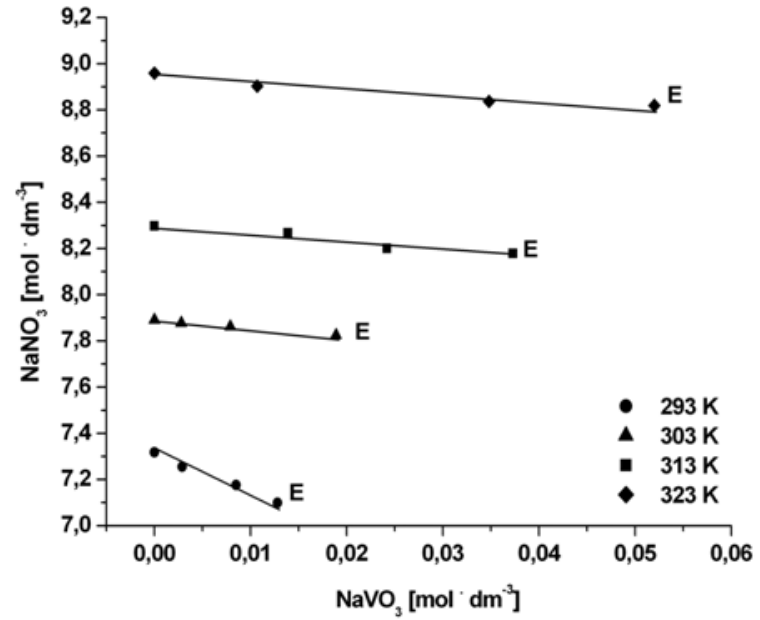

Figure 2. Branches $\mathrm{I}$ of the solubility isotherms for the $\mathrm{NaVO}_{3}-\mathrm{NaNO}_{3}-\mathrm{H}_{2} \mathrm{O}$ system

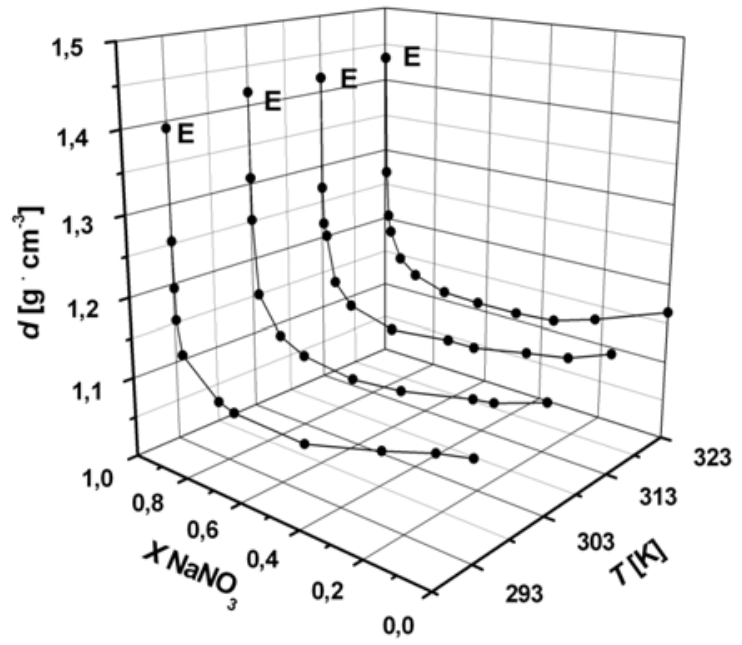

Figure 3. Changes in the density of equilibrium solutions for branches II of the solubility isotherms at temperatures $293-323 \mathrm{~K}$

be confirmed by constructing the property-composition equilibrium plot, such as the viscosity or density of the equilibrated solutions as a function of concentration of one component expressed as the molar ratio. If the new phase were to be formed, such a plot would reveal characteristic inflections or breaks ${ }^{13}$.

To confirm that conclusion, the dependence of the density of equilibrated solutions on the molar ratio of sodium nitrate was plotted. For the reasons analogous to those for the solubility polytherms, the dependence is presented in two figures (Figs. 3 and 4). Figure 3 presents the dependence of density of the equilibrated solutions on the molar ratio of sodium nitrate for the solutions saturated with sodium vanadate(V). Figure 4 presents a similar plot for the solutions saturated with sodium nitrate. An analysis of both plots supports the conclusion that in the solid phase there is no component other than $\mathrm{NaNO}_{3}$ and $\mathrm{NaVO}_{3}$. An additional basis for such a conclusion is given by the X-ray diffraction experiments, which excluded the presence of any other component in the solid phase.

\section{CONCLUSIONS}

Both the experimental data on the mutual solubility of salts in the investigated system and the literature reports ${ }^{9}$

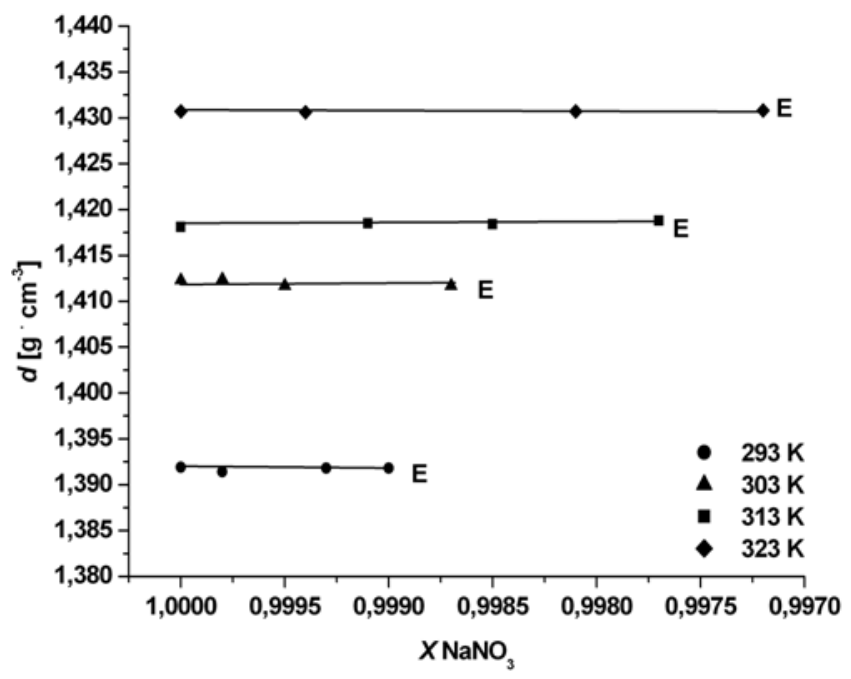

Figure 4. Density changes of the equilibrium solutions for branches I of the solubility isotherms

allow to conclude that the strong salting out effect of sodium nitrate on sodium metavanadate and the $\mathrm{NaVO}_{3}$ solubility 5 times larger than that of $\mathrm{NH}_{4} \mathrm{VO}_{3}$ at the eutonic points, are advantageous for the reaction equilibrium (4). According to the obtained results and the literature data ${ }^{9}$ the area of crystallization of sodium nitrate and sodium metavanadate on the Janecke equilibrium plot would be small compared to that for ammonium metavanadate. That indicates that the reaction equilibrium (4) is strongly shifted towards the reaction products, and reaching high efficiency for $\mathrm{NH}_{4} \mathrm{VO}_{3}$ is possible.

\section{LITERATURE CITED}

(1) Collaborative paper „Research on the new method of soda production" UMK Toruń 1969.

(2) Koneczny H., Lango M.: „Research on the ternary system $\mathrm{NaNO}_{3}-\mathrm{NH}_{4} \mathrm{NO}_{3}-\mathrm{H}_{2} \mathrm{O}$ ". UMK Toruń 1967.

(3) Niederliński A., Bukowski A., Koneczny H.: „Soda and accompanying products" WNT Warsaw 1978.

(4) Kołaczkowski A.: „Spontaneous decomposition of ammonium nitrate" Scientific papers Institute of Inorganic Technology and Mineral Fertilizers, Wrocław Technical University, Wrocław 1980.

(5) Bobrownicki W., Biskupski A., Kołaczkowski A.: „On the thermal decomposition of ammonium-sodium nitrate" Applied Chemistry, 1977, 21, 3 - 18.

(6) Trypuć M., Łyjak G.: „Application of $\mathrm{NaVO}_{3}$ for the utilization of the after-filtration liquor from Solvay's process" Industrial and Engineering Chemistry Research, 2000, 40, $2188-2192$.

(7) Trypuć M., Łyjak G.: „Solubility investigations in the $\mathrm{NH}_{4} \mathrm{Cl}+\mathrm{NaVO}_{3}+\mathrm{NH}_{4} \mathrm{VO}_{3}+\mathrm{NaCl}+\mathrm{H}_{2} \mathrm{O}$ system at $303 \mathrm{~K} "$ Journal Chemical Engineering Data, 2000, 45, 872 - 875.

(8) Trypuć M., Torski Z.: „Investigation on the optimum conditions of $\mathrm{NaCl}$ conversion into $\mathrm{NaVO}_{3}$ " Industrial and Engineering Chemistry Research, 1998, 37, 1095 - 1098.

(9) Trypuć M., Kiełkowska U.: „Solubility in the $\mathrm{NaVO}_{3}$ $+\mathrm{NH}_{4} \mathrm{VO}_{3}+\mathrm{H}_{2} \mathrm{O}$ system" Journal Chemical Engineering Data, 1997, 42, 523 - 525 .

(10) Struszyński M.: „Quantitative and technical analysis” Vol. II PWN Warszawa 1954.

(11) Williams W. J.: „Handbook of anion determination” Butterworth and Co Ltd 1979, London; (polish translation „Oznaczanie anionów” PWN Warszawa 1985).

(12) Joint Committee on Powder Diffraction Standards, Powder Diffraction File, USA 1976.

(13) Sułajmankułow K., ILIM, Frunze, Russia, 1971. 